\title{
Purification, characterization and immobilization of glucose isomerase from Streptomyces albaduncus
}

\author{
Mahmoud Abdul Megead Yassien ${ }^{1 *}$, Asif Ahmad Mohammad Jiman-Fatani ${ }^{2}$ \\ and Hani Zakarea Asfour ${ }^{2}$ \\ ${ }^{1}$ Department of Natural Products/Microbiology, Faculty of Pharmacy, King Abdulaziz University, Jeddah 21589, \\ Kingdom of Saudi Arabia. \\ ${ }^{2}$ Department of Medical Microbiology and Parasitology, Faculty of Medicine, King Abdulaziz University, Jeddah 21589, \\ Kingdom of Saudi Arabia. \\ Accepted 30 April, 2013

\begin{abstract}
Glucose isomerase produced from Streptomyces albaduncus was purified to homogeneity by ammonium sulphate precipitation, followed by ion exchange DEAE-cellulose chromatography, and finally on DEAE-Sephadex A-50 chromatography. The molecular weight of the purified enzyme was estimated to be $54 \mathrm{kDa}$ by sodium dodecyl sulphate polyacrylamide gel electrophresis (SDS-PAGE). The final preparation by the purification procedure had $10.3 \%$ final activity recovery and 13.3-fold purification. The optimum $\mathrm{pH}$ and temperature for $\mathrm{Gl}$ activity were 7 and $70^{\circ} \mathrm{C}$, respectively. In addition, the presence of the combination of $\mathrm{Mg}^{2+}$ and $\mathrm{Co}^{2+}$ ions $(5 \mathrm{mM})$ improve the Gl activity. Partially purified GI enzyme was immobilized by cross-linking with gluteraldahyde, adsorption on DEAE-Cellulose, and entrapment into polyacrylamide. Immobilization of GI enzyme caused sight decrease (3-19\% reduction) in the enzymatic activity as compared to that of the non-immobilized enzyme. The maximum enzymatic activity $(97 \%)$ and stability $(88 \%)$ was obtained in the immobilized enzyme prepared by entrapment into polyacrylamide.
\end{abstract}

Key words: Glucose isomerase, Streptomyces albaduncus, purification, immobilization.

\section{INTRODUCTION}

Glucose Isomerase (Gl) is a microbial enzyme of immense commercial significance. The enzyme is used in large quantity for the production of high fructose corn syrup (HFCS) which is widely used in the United States and Japan as an alternative to sucrose or invert sugar in the pharmaceutical, food, and beverage industry. The production of industrially important monosaccharides, such as L-glucose, L-fructose, L-ribose, L-lyxose, Dallose, and L-galactose, by glucose isomerase has recently received much attention due to potential health and medical benefits (Joo et al., 2005; Kluskens et al., 2010). Interconversion of xylose to xylulose by GI, on the other hand, serves a nutritional requirement in saprophytic bacteria. Also, it has a potential application in the bioconversion of hemicellulose to ethanol (Borgi et al., 2004; Van Vleet and Jeffries, 2009).

Due to the expense of glucose isomerase, there is direction for using the enzyme in immobilized form that can be reused several times at minimal cost (Leang et al., 2004). Over the last decade, immobilized enzymes 
have primarily been used in the bio-processes for the production of food, pharmaceuticals, and other biologically-based fine products. Cross linking, physical adsorption and entrapment among the various methods for enzyme immobilization are the most suitable methods for Gl immobilization (Song et al., 2011).

The present study was performed to purify the GI enzyme from $S$. albaduncus and to characterize some of its enzymatic properties. In addition, the Gl enzyme in partially purified form was immobilized by different methods, and its activity and stability was evaluated to select the most suitable immobilization method.

\section{MATERIALS AND METHODS}

\section{Organisms, medium and growth}

S. albaduncus is a high Gl producer strain isolated in our previous study from West Area of Saudi Arabia (Yassien and Jiman-Fatani, 2011). Microbial growth and enzyme production was carried out in a $14 \mathrm{~L}$ laboratory glass fermentor (Bioflo 110, New Brunswick Scientific Co., Inc., NJ, USA) containing $8 \mathrm{~L}$ working volume as described by Yassien and Jiman-Fatani (2012). The fermentation medium consists of $1 \% \mathrm{D}$-xylose, $2 \%$ corn steep liquor, $1 \%$ yeast extract, $0.1 \% \mathrm{MgSO}_{4}, 0.1 \%$ ammonium phosphate, $0.01 \% \mathrm{DL}$ isoleucine, $\mathrm{pH}$ adjusted to 7 . Spores from 4 to 5-day-old cultures on starch nitrate agar (20 g soluble starch, $2.0 \mathrm{~g} \mathrm{KNO}_{3}, 1.0 \mathrm{~g} \mathrm{~K}_{2} \mathrm{HPO}_{4}$, $0.5 \mathrm{~g} \mathrm{MgSO}_{4}, 0.5 \mathrm{~g} \mathrm{NaCl}, 3.0 \mathrm{~g} \mathrm{CaCO}_{3}, 0.01 \mathrm{~g} \mathrm{FeSO}_{4}, 0.01 \mathrm{~g}$ $\mathrm{MnCl}_{2}, 0.01 \mathrm{~g} \mathrm{ZnSo}_{4}, 20 \mathrm{~g}$ agar per liter ) were harvested in sterile normal saline. The final count in the spore suspension was adjusted to about $10^{5} \mathrm{CFU} / \mathrm{ml}$, as determined by the standard viable count technique. The spore suspension was used as an inoculum to give a final count of $10^{3} \mathrm{CFU} / \mathrm{ml}$ in the fermentation medium. The fermentation was operated at $30^{\circ} \mathrm{C}$ for $108 \mathrm{~h}$, using batch mode without $\mathrm{pH}$ control.

\section{Determination of microbial production of glucose isomerase}

Quantitative determination of the Gl activities was carried out as described by Bok et al. (1984). Briefly, an aliquot of the culture broth obtained after fermentation was sonified on ice for $10 \mathrm{~min}$ at 22 volts output power by using sonicator (Soniprep 150 plus, UK). Then, a $0.5 \mathrm{ml}$ of each sonified culture broth was mixed with $5 \mathrm{ml}$ of maleate buffer-salts solution containing $1 \%$ glucose and incubated in a water bath at $65^{\circ} \mathrm{C}$ for $60 \mathrm{~min}$. The mixture was cooled in ice to stop the enzymatic reaction. The amount of fructose in the prepared mixture was determined as described by Kulka (1956). One unit of $\mathrm{Gl}$ activity $(\mathrm{U})$ is defined as the amount of enzyme that produced 1 $\mu \mathrm{mol}$ of D-fructose per min under the assay conditions. Specific GI production is expressed as units of enzyme activity per gram of dry cells.

\section{Purification of glucose isomerase enzyme}

\section{Preparation of crude enzyme}

The microbial cells were harvested from the 5 days old culture by centrifugation at $12,000 \mathrm{rpm}$ for $30 \mathrm{~min}$ and washed with water twice. The cells were suspended in $0.05 \mathrm{M}$ sodium phosphate buffer ( $\mathrm{pH} 7.0$ ) containing $0.1 \%$ cetylpyridinum chloride, and the suspension was autolyzed at $40^{\circ} \mathrm{C}$. After $6 \mathrm{~h}$, the autolyzate was centrifuged and filtered. The filtrate was used as a crude enzyme preparation (Chen and Anderson, 1979).

\section{Purification of the crude enzyme}

Unless otherwise indicated, all steps of the purification were carried out at $4^{\circ} \mathrm{C}$. Solid ammonium sulfate was added to the crude enzyme preparation to give $70 \%$ saturation, and the precipitate was discarded. More ammonium sulfate was added to the supernatant to give $90 \%$ saturation. The precipitate was collected, dissolved in $0.05 \mathrm{M}$ sodium phosphate buffer ( $\mathrm{pH} 7.0)$, and dialyzed overnight against the same buffer. The dialysate was centrifuged at $12,000 \mathrm{xg}$ for $10 \mathrm{~min}$. After dialysis and centrifugation, the obtained supernatant is considered as partially purified enzyme (PPE). The collected supernatant was applied to a column $(2.5 \times 16 \mathrm{~cm})$ of DEAE-cellulose (Sigma Aldrich) which was previously equilibrated with $0.05 \mathrm{M}$ sodium phosphate buffer ( $\mathrm{pH} 7.0)$. The enzyme was eluted with the same buffer containing a linear gradient of $\mathrm{NaCl}(0$ to $1 \mathrm{M} \mathrm{NaCl}$ ) at a flow rate of $50 \mathrm{ml} / \mathrm{h}$. About $2.0 \mathrm{ml}$ fraction was collected in different tubes. The active fractions (F-24 to -32) were collected, dialyzed overnight with the same buffer, and centrifuged at $12,000 \mathrm{xg}$ for $10 \mathrm{~min}$. The supernatant was applied to a column of DEAE-Sephadex A-50 (1.5 by $20 \mathrm{~cm})$ which was previously equilibrated with $0.05 \mathrm{M}$ sodium phosphate buffer $(\mathrm{pH} 7.0)$. The enzyme was eluted with the same buffer containing a linear gradient of $\mathrm{NaCl}(0$ to $1 \mathrm{M} \mathrm{NaCl}$ ) at a flow rate of $30 \mathrm{ml} / \mathrm{h}$. About 1.0 $\mathrm{ml}$ fraction was collected in different tubes. The active fractions ( $\mathrm{F}$ 12 to -16 ) were collected, dialyzed overnight against same buffer, and the homogeneity of the purified enzyme and its molecular mass were measured by SDS-polyacrylamide gel electrophoresis.

\section{Methods of immobilization of GI enzymes}

All the chemicals used in the immobilization processes are from Sigma Aldrich.

\section{Cross-linking using gluteraldahyde}

An aqueous gluteraldahyde solution was added to the PPE preparation to give a final concentration of $2.5 \%$, in a $50 \mathrm{ml}$ glass beaker, with sufficient stirring to thoroughly intermix both. The $\mathrm{pH}$ of the mixture was adjusted to 7.0 with careful addition of $1 \mathrm{~N} \mathrm{NaOH}$. The mixture was left at room temperature for $2 \mathrm{~h}$, with constant stirring with a glass rod for the first $30 \mathrm{~min}$. The coherent mass obtained was broken up by mild stirring, washed with distilled water, recovered by centrifugation at $2000 \mathrm{xg}$ for $15 \mathrm{~min}$. The collected sediment was air dried and used to evaluate the enzymatic activity (Tyagi et al., 1999).

\section{Adsorption on DEAE-Cellulose}

This process was carried out as described by Chen and Anderson (1979). Suspension of $500 \mathrm{mg}$ (dry weight) of DEAE-Cellulose in $0.05 \mathrm{M}$ sodium phosphate buffer $(\mathrm{pH} 7.0)$ was stirred gently at $4^{\circ} \mathrm{C}$. The PPE preparations was added and stirred for $30 \mathrm{~min}$ at the same temperature. The enzyme-support complex obtained was washed by the same buffer, allowed to dry, and then assayed for enzyme activity.

\section{Entrapment into polyacrylamide}

The Gl enzyme in the PPE preparation was entrapped into polyacrylamide by free-radical cross-linking polymerization of acrylamide in aqueous solutions. The acrylamide (2.85 g), 
Table 1. Purification steps of Gl enzyme from S. albaduncus culture.

\begin{tabular}{lccccc}
\hline Purification steps & $\begin{array}{c}\text { Total protein } \\
(\mathbf{m g})\end{array}$ & $\begin{array}{c}\text { Total activity } \\
(\mathbf{U})\end{array}$ & $\begin{array}{c}\text { Specific activity } \\
(\mathbf{U} / \mathbf{m g})\end{array}$ & $\begin{array}{c}\text { Yield } \\
(\%)\end{array}$ & $\begin{array}{c}\text { Purification } \\
\text { fold }\end{array}$ \\
\hline Crude enzyme & 2728 & 4736 & 1.7 & 100 & 1.00 \\
Ammonium sulfate precipitation $(70$ to $90 \%)$ & 342 & 2682 & 7.8 & 56.6 & 4.6 \\
DEAE-Cellulose & 122 & 1486 & 12.2 & 31.4 & 7.2 \\
DEAE-Sephadex A-50 & 22 & 498 & 22.6 & 10.5 & 13.3 \\
\hline
\end{tabular}

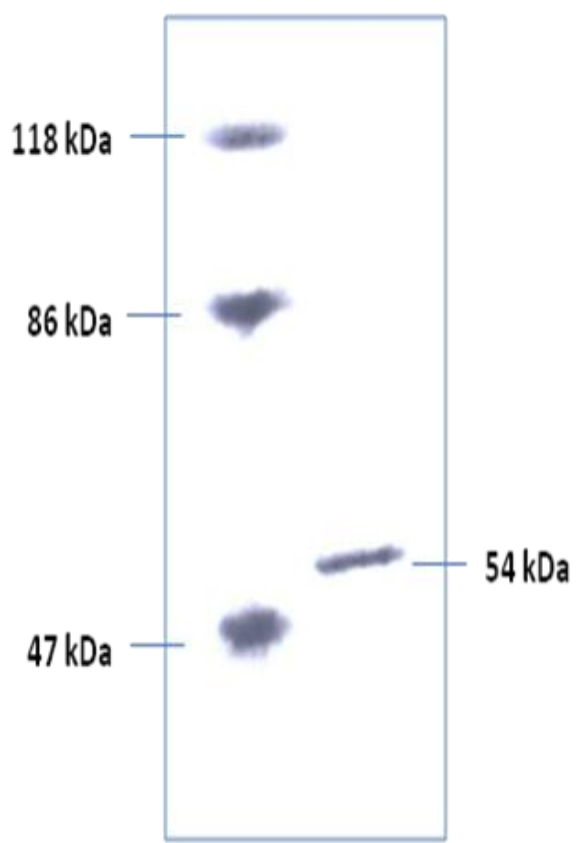

Figure 1. SDS-PAGE of purified $\mathrm{Gl}(20 \mu \mathrm{g})$ produced by $S$. albaduncus. Lane 1 : Molecular mass standards ( $\beta$-galactosidase, $118 \mathrm{kDa}$; Bovine serum albumin, $86 \mathrm{kDa}$; ovalbumine, $47 \mathrm{kDa}$ ). Lane 2: purified $\mathrm{Gl}$ enzyme produced by $S$. albaduncus.

ammonium persulfate $(10 \mathrm{mg})$ and bisacrylamide $(0.15 \mathrm{~g})$ were dissolved in distilled water $(20 \mathrm{ml})$. After the addition of TEMED (1 $\mathrm{ml}$ ) and enzyme preparation $(1 \mathrm{ml})$, the solution was poured into a flat bottom Petri dish. Polyacrylamide hydrogels were cut into equal size cubes (1 to $2 \mathrm{~mm}$ ). Gel cubes were washed thoroughly three times with distilled water and used to evaluate the activity of the immobilized enzyme (Demirel et al., 2006).

In each experiment, the activity yield of the immobilized enzymatic preparation was calculated with respect to the original activity before immobilization. Each experiment was carried out in triplicate. The immobilized preparation was recovered after the first assay and reused for a total of 7 times at $48 \mathrm{~h}$ intervals.

\section{Statistical analysis}

Statistical significance between means was tested by analysis of variance and student t-test using Instat-ANOVA software. The differences between means were considered statistically significant when the test yielded a value $\mathrm{P}<0.05$.

\section{RESULTS}

\section{Purification of the GI enzyme}

The purification of Gl enzyme is summarized in Table 1. The enzyme was purified to homogeneity by ammonium sulfate precipitation, DEAE-cellulose chromatography, and finally ion exchange chromatography on DEAESephadex A-50. The final preparation had $10.5 \%$ activity recovery and approximately 13.3-fold purification. The purified Gl enzyme had a single protein band on SDSPAGE with approximate relative molecular mass $54 \mathrm{kDa}$ (Figure 1).

\section{Effects of different factors on the activity of the GI enzyme}

\section{Effect of temperature}

To observe the effects of temperature on the Gl activity, the reaction mixture with the purified enzyme sample was incubated at various incubation temperatures (50 to $90^{\circ} \mathrm{C}$ ) for $60 \mathrm{~min}$ and the produced fructose was quantitatively determined as described before. According to the obtained results (Figure 2), the maximum enzymatic activity (85 to $100 \%$ ) was obtained at a temperature range of 65 to $75^{\circ} \mathrm{C}$, with optimum temperature at $70^{\circ} \mathrm{C}$.

\section{Effect of $\mathrm{pH}$}

For studying the effects of $\mathrm{pH}$ on the $\mathrm{Gl}$ activity, the $\mathrm{pH}$ of the reaction mixture was adjusted at different values $(\mathrm{pH}$ 5 to 9 ) and incubated at $70^{\circ} \mathrm{C}$ for $60 \mathrm{~min}$. The produced fructose was quantitatively determined as described before. As shown in Figure 3, a promising enzymatic activity (84 to $100 \%$ of the highest activity) was obtained over the $\mathrm{pH}$ range 6.5 to 8 , while the optimum $\mathrm{pH}$ was 7 .

\section{Effect of metal ions}

Regarding the effects of metal ions, the presence of $\mathrm{Mg}^{2+}$ or $\mathrm{Co}^{2+}(5 \mathrm{mM})$ in the reaction mixture enhanced the 


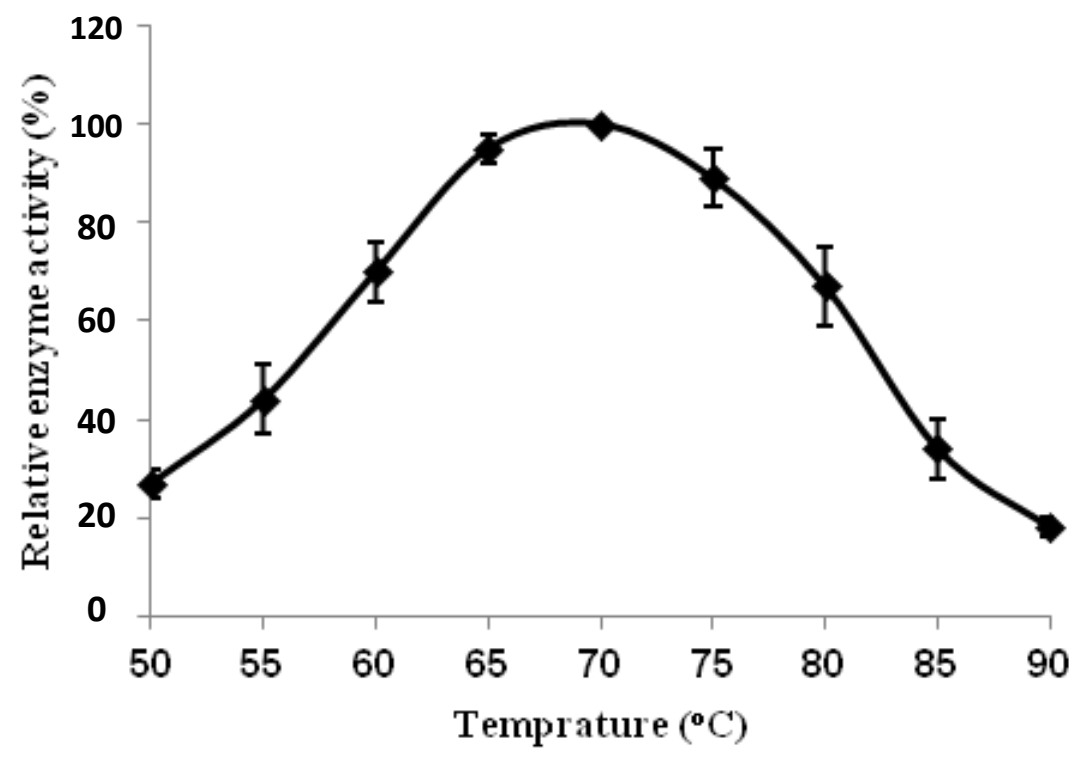

Figure 2. Effects of temperature on the Gl activity.

The enzymatic reaction mixture was incubated at different temperatures (50 to $90^{\circ} \mathrm{C}$ ) for $60 \mathrm{~min}$ and the produced fructose was quantitatively determined and compared with the maximum value.

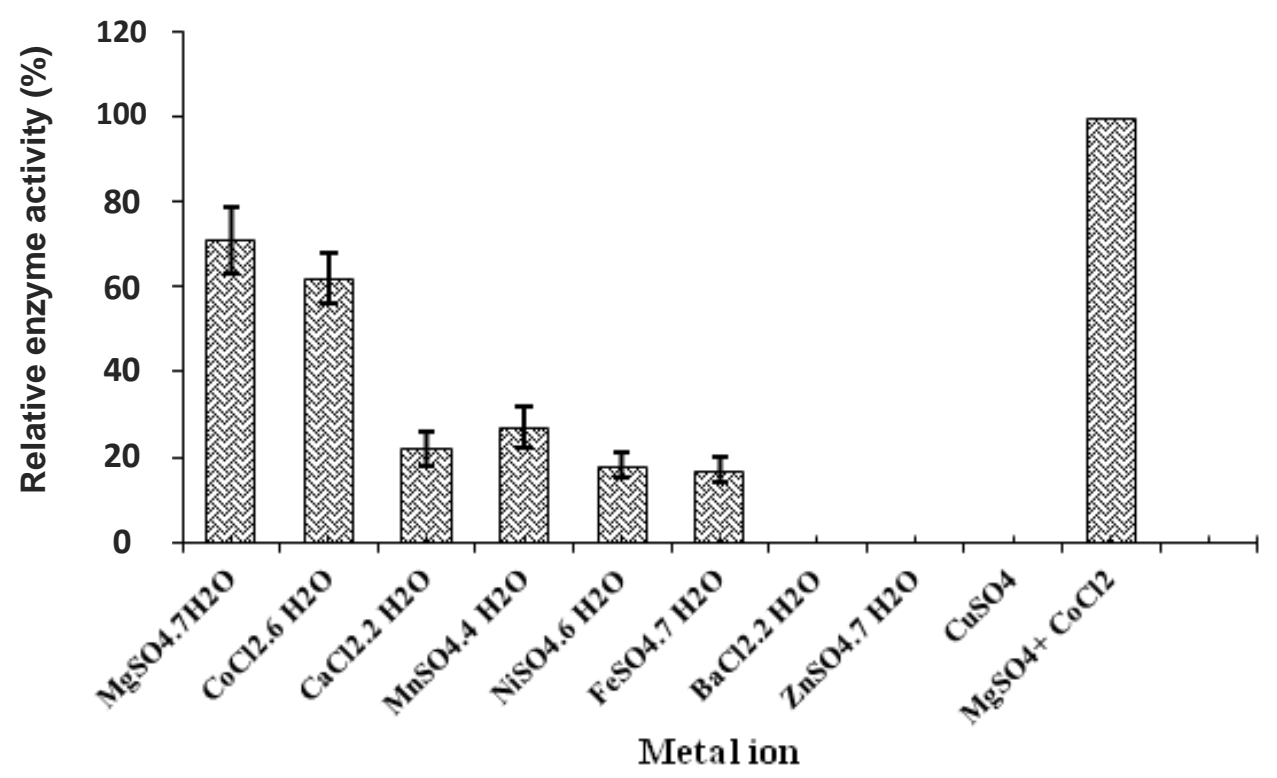

Figure 3. Effects of $\mathrm{pH}$ on the $\mathrm{Gl}$ activity.

The $\mathrm{pH}$ of enzymatic reaction mixture was adjusted to different $\mathrm{pH}(5$ to 9$)$ and incubated at $70^{\circ} \mathrm{C}$ for $60 \mathrm{~min}$. The produced fructose was quantitatively determined and compared with the maximum value.

enzymatic activity and the combination of the two metal ions induced the highest enzymatic activity. On the other hand, weak $\mathrm{Gl}$ activity was observed in the presence of $\mathrm{Ca}^{2+}, \mathrm{Mn}^{2+}, \mathrm{Ni}^{2+}$ and $\mathrm{Fe}^{2+}$ (17 to $27 \%$ of the maximum activity). While the enzymatic activity was inhibited in the presence of $\mathrm{Ba}^{2+}, \mathrm{Zn}^{2+}$ and $\mathrm{Cu}^{2+}$ (Figure 4).

\section{Immobilization of the GI enzyme}

The activity yield of the different immobilized preparations was relatively evaluated as compared to that of the original non immobilized PPE preparation. According to the obtained results, the relative activities of the immo- 


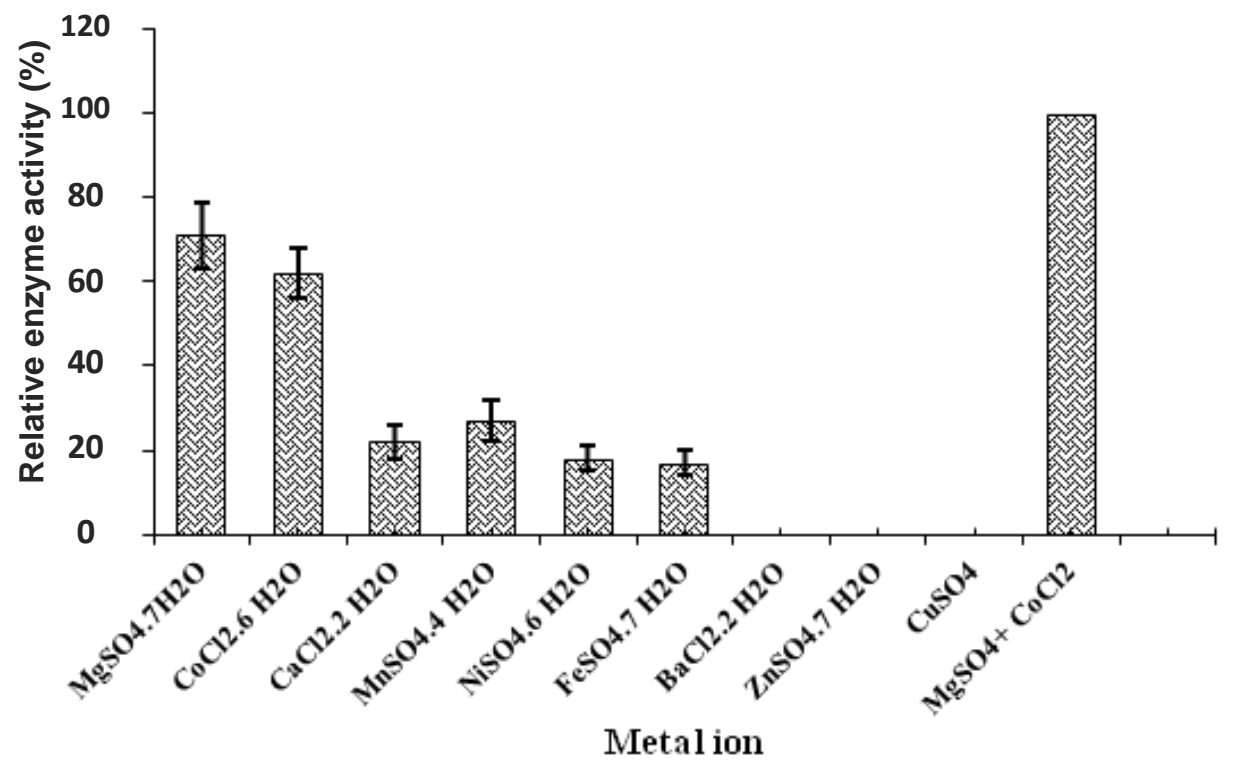

Figure 4. Effects of different metal ions on the Gl activity. Different types of metal ions were added to the reaction mixture at concentration of $5 \mathrm{mM}$. The reaction mixture was adjusted to $\mathrm{pH} 7$ and incubating at $70^{\circ} \mathrm{C}$ for $60 \mathrm{~min}$. The produced fructose was quantitatively determined and compared with the maximum value.

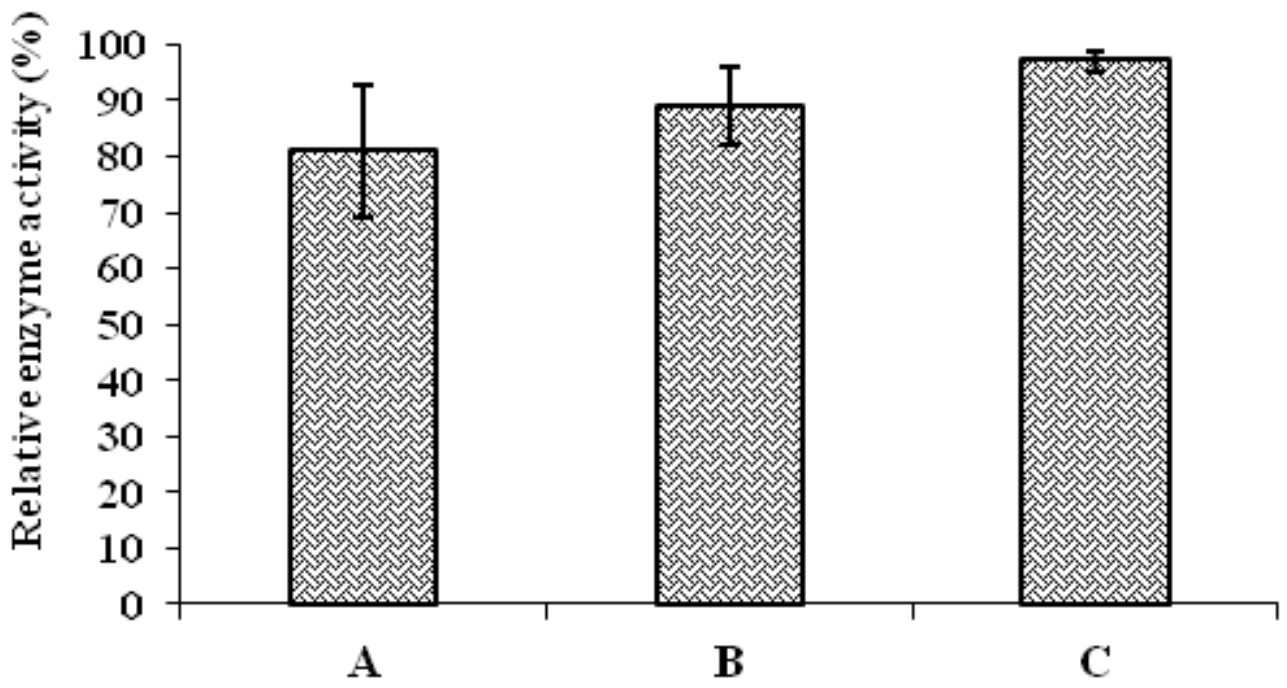

\section{Different forms of immoblized enzymes}

Figure 5. Relative enzymatic activities of the different forms of immobilized Gl enzyme as compared to that of the original non immobilized PPE preparations. A: cross-linking with gluteraldehyde; B: adsorption on DEAE-Cellulose; C: entrapment into polyacrylamide.

bilized preparations by cross-linking with gluteraldahyde, adsorption on DEAE Cellulose, and entrapment into polycrylamide were 81,89 and $97 \%$, respectively (Figure 5).

Immobilized GI preparations were stored at $+4^{\circ} \mathrm{C}$, and their enzymatic activities were measured periodically over duration of 14 days. Upon 14 days of storage, the preserved activity of the immobilized preparations by cross-linking, adsorption on DEAE-Cellulose, and entrapment into polycrylamide were 65,78 and $88 \%$, respectively, as compared to the original activity (Table 2). 
Table 2. Relative enzymatic activity of different forms of immobilized Gl enzyme along a duration of 14 days.

\begin{tabular}{lccc}
\hline \multirow{2}{*}{ The duration time (days) } & \multicolumn{3}{c}{ The relative enzymatic activity (\%) } \\
\cline { 2 - 4 } & Cross-linkage by gluteraldahyde & $\begin{array}{c}\text { Adsorption on } \\
\text { DEAE-cellulose }\end{array}$ & Entrapment into polyacrylamide \\
\hline 0 & 100 & 100 & 100 \\
2 & 91 & 94 & 96 \\
4 & 83 & 89 & 94 \\
6 & 78 & 85 & 92 \\
8 & 73 & 82 & 90 \\
10 & 69 & 80 & 89 \\
12 & 67 & 79 & 88 \\
14 & 65 & 78 & 88 \\
\hline
\end{tabular}

\section{DISCUSSION}

The effective catalytic properties of Gl enzymes have already prompted their introduction into several industrial products and processes (Kirk et al., 2002).

The efficiency of production of Gl from Streptomyces species has been documented previously (AbdulRahman et al., 2011; Bhasin and Modi, 2012). A high Glproducer Streptomyces isolate, identified as Streptomyces albaduncus, was selected for the present studies (Yassien and Jiman-Fatani, 2011). To optimize the activity of the Gl enzyme produced by the selected strain, it is essential to study the effect of some factors on the purified enzyme. Preparation of the purified GI enzyme from culture supernatant of $S$. albaduncus was started by ammonium sulphate precipitation, followed by ion exchange DEAE-cellulose chromatography, and finally on DEAE-Sephadex A-50 chromatography. The enzyme homogeneity in the final product was confirmed by formation of single protein band of estimated molecular weight $54 \mathrm{kDa}$ in the SDS-PAGE. Kawai et al. (1994) purified Gl enzymes from culture supernatant of Bifidobacterium adolescent with estimated molecular weight of $53 \mathrm{kDa}$, while the $\mathrm{Gl}$ enzyme produced by Streptomyces flavogriseus has a smaller molecular weight of $43 \mathrm{kDa}$ (Chen and Anderson, 1979).

The Gl catalytic activity may be affected by some factors such as temperature, $\mathrm{pH}$, and metal ions. The optimum temperature of $\mathrm{Gl}$ activity may be ranged from 60 to $80^{\circ} \mathrm{C}$ (Bhosale et al., 1996). In the present study, the optimum temperature of the enzymatic activity of Gl produced by $S$. albaduncus is $70^{\circ} \mathrm{C}$. The same optimum temperature was reported by Chen and Anderson (1979). However, higher optimum temperature $\left(80^{\circ} \mathrm{C}\right)$ for $\mathrm{Gl}$ activity was observed in the study of Azin et al. (1997) and Srivastava et al. (2010). On the other hand, lower temperature $\left(60^{\circ} \mathrm{C}\right)$ was the optimum for the activity of $\mathrm{Gl}$ produced by Lactobacillus xylosus (Kawai et al., 1994).

A suitable $\mathrm{Gl}$ activity can be obtained over a $\mathrm{pH}$ range from 6 to 8 (Kawai et al., 1994). In the present study, a promising enzyme activity was observed over the range of 6.5 to 8 , with optimum level at $\mathrm{pH} 7$ which is in agreement with that reported by Kawai et al. (1994). While, slight alkaline condition, $\mathrm{pH} 7.5$ and 8 , are the optimum for the activity of Gl enzyme produced by Streptomyces flavogriseus and Streptomyces phaeochromogenes NRRL B-3559, respectively (Standberg and Smiley, 1971; Chen and Anderson, 1979).

Gl enzymes require different types of metal ions such as $\mathrm{Mg}^{2+}, \mathrm{Co}^{2+}$, or $\mathrm{Mn}^{2+}$ or a combination of these cations to enhance their catalytic activities. Although both $\mathrm{Mg}^{2+}$ and $\mathrm{Co}^{2+}$ are essential for the activity, they play differential roles. While $\mathrm{Mg}^{2+}$ is superior to $\mathrm{Co}^{2+}$ as an activator, $\mathrm{Co}^{2+}$ is responsible for stabilization of the enzyme by holding the ordered conformation, especially the quaternary structure of the enzyme (Gaikwad et al., 1992; Bhosale et al., 1996). In the present study, the maximum enzyme activity of $\mathrm{Gl}$ produced by $S$. albaduncus was observed in the presence of the combination of $\mathrm{Mg}^{2+}$ and $\mathrm{Co}^{2+}$ ions $(5 \mathrm{mM})$. The reducing effects of some metal ions such as $\mathrm{Ag}^{1+}, \mathrm{Hg}^{2+}, \mathrm{Cu}^{2+}, \mathrm{Zn}^{2+}$, $\mathrm{Ni}^{2+}$ and $\mathrm{Ca}^{2+}$ on the Gl activity observed in the present study was also reported by other investigators Chen and Anderson (1979), Smith et al. (1991) and Kawai et al. (1994).

Because enzymes are biocatalysts that promote the rate of reactions without being themselves consumed, they may be used repeatedly as long as they remain active. Therefore, there is an incentive to use enzymes in an immobilized form so that they may be retained in a biochemical reactor to catalyze further the subsequent feed and allow operation in a continuous mode and consequently lowers cost of its use (Cabral, 2001). Also, immobilizations of enzymes of partially purified preparations are sometimes preferred to avoid costly purification processes or to increase catalytic stability (Tanino et al., 2010).

In the present study, immobilization of GI from the PPE preparations of $S$. albaduncus was carried out by three different methods; cross-linking with gluteraldahyde, adsorption on DEAE-Cellulose, and entrapment into poly- 
crylamide. The efficiency of these three immobilization methods was confirmed previously (Bhosale et al., 1996; Cabral, 2001; Demirel et al., 2006). In the present study, the obtained results revealed that the most suitable Gl immobilization process is the entrapment into polyacrylamide, by which the immobilization process did not significantly $(P<0.05)$ reduced the enzymatic activity as compared with that of the non immobilized form. Enzymes in such immobilization process is physically bound within the matrices of the gel network by forming the gel in the presence of the enzyme. Physical or chemical alteration of the enzyme appears to be much less with this treatment as compared to the other two immobilization methods that may employ an interaction between the enzyme and insoluble carrier (Standberg and Smiley, 1971). The results obtained in the present report can be used as initial step for production of GI enzyme from $S$. albaduncus at industrial level and improve its efficiency through enzyme immobilization.

\section{ACKNOWLEDGEMENTS}

This project was funded by the Deanship of Scientific Research (DSR), King Abdulaziz University, Jeddah; under grant No (1432/166/223). The authors, therefore, acknowledge with thanks DSR technical and financial support.

\section{REFERENCES}

Abdul-Rahman N, Hussain MA, Hasan M, Jahim JM (2011). Mathematical modeling of fructose production by immobilized glucose isomerase as a function of temperature and $\mathrm{pH}$ variations. Afr. J. Biotech. 10(14):2766-2779.

Azin M, Moazami N, Nemat-Gorgani M (1997). Production, purification and immobilization of glucose isomerase from Streptomyces olivochromogenes PTCC 1547. World J. Microbiol. Biotechnol. 13:597-598.

Bhasin S, Modi HA (2012). Optimization of fermentation medium for the production of glucose isomerase using Streptomyces $s p$. SB-P1. Biotech. Res. Int. Article ID 874152, 1-10.

Bhosale SH, Rao MB, Deshpande VV (1996). Molecular and industrial aspects of glucose isomerase. Microbiol. Rev. 60:280-300.

Bok SH, Seidman M, Wopat PW (1984). Selective isolation of acidophilic Streptomyces strains for glucose isomerase production. Appl. Environ. Microbiol. 47:1213-1215.

Borgi MA, Srih-Belguith K, Ben Ali M, Mezghani M, Tranier S, Haser R, Bejar S (2004). Glucose isomerase of the Streptomyces sp. SK strain: purification, sequence analysis and implication of alanine 103 residue in the enzyme thermostability and acidotolerance. Biochimie 86(8):561-8.

Cabral JMS (2001). Biotransformations. In: Ratledge C and Kristiansen B (eds) Basic Biotechnology, Cambridge University Press, Cambridge. pp. 471-501.

Chen WP, Anderson AW (1979). Purification, immobilization, and some properties of glucose isomerase from Streptomyces flavogriseus. Appl. Environ. Microbiol. 38:1111-1119.
Demirel G, Ozcetin G, Sahin F, Tumturk H, Aksoy S, Hasirci N (2006). Semi-interpenetrating polymer networks (IPNs) for entrapment of glucose isomerase. React. Funct. Polym. 66:389-394.

Gaikwad SM, Rao MB, Deshpande VV (1992). D-Glucose/xylose isomerase from Streptomyces. Differential roles of magnesium and cobalt ions. Enzyme Microb. Technol. 14:317-320.

Joo GJ, Shin S, Heo GY, Kim YM, Rhee IK (2005). Molecular cloning and expression of a thermostable xylose (Glucose) isomerase gene, xylA, from Streptomyces chibaensis. J. Microbiol. 43(1):34-7.

Kawai Y, Konishi K, Horitsu H, Sakurai H, Takamizawa K, Suzuki T, Kawai K (1994). Purification and characterization of D-xylose isomerase from Bifidobacterium adolescentis. Biosci. Biotech. Biochem. 58(4):691-691.

Kirk O, Borchert TV, Fuglsang CC (2002). Industrial enzyme applications. Curr. Opin. Biotecnol. 13:345-351.

Kluskens LD, Zeilstra J, Geerling AC, de Vos WM, van der Oost J (2010). Molecular characterization of the glucose isomerase from the thermophilic bacterium Fervidobacterium gondwanense. Environ. Technol. 31(10):1083-90.

Kulka RG (1956). Colorimetric estimation of ketopentoses and ketohexoses. Biochem. J. 63:542-548.

Leang K, Takada G, Fukai Y, Morimoto K, Granström TB, Izumori K (2004). Novel reactions of L-rhamnose isomerase from Pseudomonas stutzeri and its relation with D-xylose isomerase via substrate specificity. Biochim. Biophys. Acta. 1674(1):68-77.

Smith CA, Rangarajan M, Hartley BS (1991). D-Xylose (D-glucose) isomerase from Arthrobacter strain NRRL B3728. Biochem. J. 277:255-261.

Song YS, Kim JE, Park C, Kim SW (2011). Enhancement of glucose isomerase activity by pretreatment with substrates prior to immobilization. Korean J. Chem. Eng. 28(4):1096-1100.

Srivastava P, Shukla S, Choubey SK, Gomase VS (2010). Isolation, purification, characterization of glucose isomerase enzyme form Streptomyces species isolated from Parbhani Region. J. Enzyme Res. 1(1):1-10.

Standberg GW, Smiley KL (1971). Free and Immobilized Glucose Isomerase from Streptomyces phaeochromogenes. Appl. Microbiol. 21(4):588-593.

Tanino T, Hotta A, Ito T, Ishii J, Yamada R, Hasunuma T, Ogino C, Ohmura N, Ohshima T, Kondo A (2010). Construction of a xylosemetabolizing yeast by genome integration of xylose isomerase gene and investigation of the effect of xylitol on fermentation. Appl. Microbiol. Biotechnol. 88(5):1215-21.

Tyagi R, Batra R, Gupta MN (1999). Amorphous enzyme aggregates: Stability toward heat and aqueous-organic cosolvent mixtures. Enzyme Microb. Technol. 24:348-354.

Van Vleet JH, Jeffries TW (2009). Yeast metabolic engineering for hemicellulosic ethanol production. Curr. Opin. Biotechnol. 20(3):3006.

Yassien MAM, Jiman-Fatani AM (2011). Production of glucose isomerase by Streptomyces species isolated from West Area of Saudi Arabia. Arab J. Lab. Med. 37(3):635-644.

Yassien MAM, Jiman-Fatani AM (2012). Optimization of glucose isomerase production by Streptomyces albaduncus. Afr. J. Microbiol. Res. 6(12):2976-2984. 